ISSN 1412-2936

EISSN 2549-7308

\title{
ANALISIS STRATEGI SOSIALISASI PASAR MODAL DAN PENGARUHNYA TERHADAP KEPUTUSAN MASYARAKAT BERINVESTASI DI ERA INDUSTRI 4.0
}

\author{
Ade Della Oktapia ${ }^{1}$ \\ adedellaoktapia@gmail.com¹ \\ Anggi Andrian² \\ anggiandrian63@gmail.com² \\ Universitas Bangka Belitung
}

\begin{abstract}
ABSTRAK
Penelitian ini bertujuan untuk mengetahui pengaruh secara parsial dan stimultan beberapa variabel yang ada terhadap strategi sosialisasi pasar modal dan keputusan masyarakat terutama mahasiswa Jurusan Manajemen Fakultas Ekonomi berinvestasi di pasar modal di era Revolusi Industri (4.0). Penelitian ini merupakan penelitian kuantitatif. Sumber data utama dari penelitian ini yaitu bersumber dari hasil responden dan data juga didapat dari studi kepustakaan.

Hasil analisis dari penelitian ini yaitu : (a) adanya suatu hubungan yang signifikan secara parsial antara sosialisasi pasar modal melalui seminar pasar modal berpengaruh terhadap keputusan responden untuk berinvestasi di pasar modal di Era Revolusi Industri (4.0). (b) Tidak adanya hubungan yang signifikan secara parsial antara sosialisasi dan pasar modal melalui kampanye "yuk nabung saham" berpengaruh terhadap keputusan responden untuk berinvestasi.(c) Tidak adanya hubungan yang signifikan secara parsial antara sosialisasi pasar modal melalalui aplikasi investasi (Invisee) tidak berpengaruh terhadap keputusan responden untuk berinvestasi di Era industri 4.0.(d) adanya suatu hubungan yang cukup signifikan secara simultan antara variable strategi sosialisasi pasar modal terhadap keputusan masyarakat berinvestasi di pasar modal pada Era Revolusi Industri(4.0).
\end{abstract}

Kata kunci : Pasar modal, Revolusi industri, keputusan berinvestasi, aplikasi investasi. 


\section{PENDAHULUAN}

Era Revolusi Industri keempat ini diwarnai oleh kecerdasan buatan (artificial intelligence), super komputer, rekayasa genetika, teknologi nano, mobil otomatis, dan inovasi. Perubahan tersebut terjadi dalam kecepatan eksponensial yang akan berdampak terhadap ekonomi, industri, pemerintahan, dan politik. Pada era ini semakin terlihat wujud dunia yang telah menjadi kampung global. Industri 4.0 adalah sebuah istilah yang diciptakan pertama kali di Jerman pada tahun 2011 yang ditandai dengan revolusi digital. Industri ini merupakan suatu proses industri yang terhubung secara digital yang mencakup berbagai jenis teknologi, mulai dari 3D printing hingga robotik yang diyakini mampu meningkatkan produktivitas (Satya, 2018). Dengan perkembangan teknologi yang semakin canggih,dimana dunia kini telah memasuki era revolusi industri 4.0, yakni menekankan pada pola digital economy, artificial intelligence, big data, robotic, dan lain sebagainya atau dikenal dengan fenomena disruptive innovation. Menghadapi tantangan tersebut masyarakat serta berbagai perguruan tinggi pun dituntut untuk berubah mengikuti perkembangan zaman (Rohida, Sos, \& Si, 2018). Dengan adanya perkembangan zaman yang semakin maju masyarakat dituntut untuk ikut andil dalam meningkatkan pertumbuhan ekonomi indonesia melalui kegiatan investasi di pasar modal.

Pasar modal mempunyai peranan penting dalam pembangunan ekonomi suatu negara. Dengan adanya pasar modal investor individu maupun badan usaha dapat menyalurkan kelebihan dana yang dimilikinya untuk diinvestasikan di pasar modal, dan para pengusaha dapat memperoleh dana tambahan modaluntuk memperluas jaringan usahanya dari para investor yang berada di pasar modal (Riyadi, n.d.). Individu yang telah mencukupi kebutuhan pokoknya, maka kegiatan ekonomi selanjutnya bertambah menjadi investasi. Ragam investasi ini bermacammacam diantaranya adalah tabungan, emas, tanah, sertifikat

berharga (saham dan obligasi) dan lainlain. Investasi bukan untuk dinikmati saat ini namun untuk masa yang akan datang. Investasi dapat diartikan sebagai penundaan konsumsi sekarang untuk digunakan di dalam produksi yang efisien selama periode waktu tertentu. Investasi di sektor pasar modal merupakan salah satu sumber alternatif pendanaan baik bagi pemerintah maupun swasta. Pemerintah yang membutuhkan dana dapat menerbitkan obligasi atau surat utang dan menjualnya ke masyarakat melalui pasar modal. Demikian juga swasta yang dalam hal ini adalah perusahaan yang membutuhkan dana dapat menerbitkan efek, baik dalam bentuk saham maupun obligasi dan menjualnya ke masyarakat melalui pasar modal (Mubarok, 2018) .

Pertumbuhan investor di pasar modal Indonesia sebagai salah satu alternatif berinvestasi masyarakat dinilai cukup baik. Tercatat pada tahun 2018 investor di pasar modal mencapai 1.617.367 SID mengalami kenaikan sebesar 44,06\% jika dibandingkan pada tahun sebelumnya yang hanya tercatat sebesar 1.122.668 SID ditahun 2017(Kustodian \& Efek, 2018) . Peningkatan jumlah investor ini merupakan hasil dari upaya yang telah dilakukan KSEI dengan dukungan dan kerja sama dari Otoritas Jasa Keuangan (OJK), Bursa Efek Indonesia (BEI). 
Meskipun terlihat mengalami peningkatan tetapi jumlah investasi di pasar modal masih rendah, hal ini disebabkan minimnya pengetahuan masyarakat tentang investasi di pasar modal. Bursa Efek Indonesia (BEI) selaku pengelola penjualan efek di Indonesia terus melakukan upaya-upaya untuk meningkatkan investasi masyarakat di pasar modal, Salah satu langkah yang diambil oleh BEI di Era Revolusi Industri

4.0 ini adalah melakukan sosialisasi dan membuka stand di berbagai event yang besar untukmemperkenalkan pasar modal kepada masyarakat (Harry, 2017). Negara indonesia merupakan negara yang sedang berkembang dimana orientasi secara finansial masyarakatnya masih berjangka pendek atau dalam kategori saving society (menabung). Bila dibandingkan dengan negara maju orientasinya lebih ke jangka panjang atau dalam kategori investing society. Kesadaran akan pengelolaan keuanggan mereka sudah sedemikian besarnya hingga mampu menyisihkan $30 \%$ pendapatannya untuk investasi. Oleh karena itu, diperlukan edukasi publik yang intensif dan berkelanjutan guna mengubah masyarakat dari saving society ke investing society (Ari, 2009:52). Edukasi yang dilakukan secara bertahap diharapkan mampu membangun motivasi masyarakat untuk beralih dari menabung menjadi berinvestasi (Wibowo, 2019). Dengan adanya sosialisasi seperti "Yuk Nabung Saham" bertujuan untuk meningkatkan kesadaran masyarakat untuk berinvestasi di pasar modal dengan membeli saham secara rutin dan berkala. Bagi masyarakat yang ingin mengikuti kegiatan menabung saham, masyarakat diwajibkan untuk membuka rekening efek di perusahaan sekuritas. Setelah rekening efek jadi, masyarakat dapat menyetorkan dana secara rutin, ataupun menggunakan fasilitas "auto transfer" di setiap periode yang telah ditentukan dan kemudian membeli saham secara rutin. Selain sosialisasi "Yuk Nabung Saham", $\mathrm{BEI}$ juga mengadakan program edukasi mengenai investasi di pasar modal, khususnya kepada kalangan akademisidi kampus, mahasiswa menjadi perhatian khusus dalam program edukasi pasar modal BEI, karena mahasiswa merupakan aset dimasa mendatang yang akan mengisi industri keuangan di pasar modal (Mar'ati, n.d.) .Salah satu yang menjadi obyek sasaran utama PT Bursa Efek Indonesia (BEI) dalam menjaring investor-investor baru adalah dengan mendirikan Galeri Investasi yang ada di setiap Universitas, termasuk galeri investasi yang ada di Universitas Bangka Belitung. Dengan adanya galeri investasi ini dapat memberikan wawasan mengenai investasi di pasar modal. Dengan demikian jumlah investor baru Hal ini menunjukan besarnya partispasi mahasiswa dalam berinvestasi. Walapun minat investasi mahasiwa cukup tinggi terutama saat di awal pembelajaran, namun tidak sedikit dari mahasiswa yang mengurungkan niatnya ketika teori yang dipelajari dibangku kuliah diperaktikan di dunia nyata. Ada banyak faktor yang mempengaruhi mengapa hal tersebut terjadi, diataranya adalah minimnya sisa uang saku yang bisa digunakan untuk di investasikan, kurangnya waktu untuk melakukan dan mengawasi transaksi, serta edukasi investasi yang masih terbatas. Dasar Keputusan Untuk Melakukan Investasi terdiri dari tingkat return harapan, tingkat risiko serta hubungan antara return dan risiko. Perkembangan teknologi yang semakin maju akan mempermudah mahasiswa maupun masyarakat dalam melakukan investasi di pasar modal. Namun, untuk memahami hal tersebut perlu dilakukan edukasi terlebih dahulu. Dengan adanya kemudahan-kemudahan yang diberikan oleh pihak sekuritas, teknologi yang semakin canggih, serta sosialisasi yang dilakukan, diharapkan dapat memberikan dampak positif terhadap pengambilan keputusan dalam berinvestasi, khususnya investasi di pasar modal guna meningkatkan perekonomian negara Indonesia agar bisa menjadi negara yang maju.

\section{TEORI DAN HIPOTESIS}

\section{Revolusi Industri 4.0}

Konsep revolusi industri 4.0 pertama kali diperkenalkan oleh Profesor Klaus 
Schwab. Ekonom terkenal asal Jerman

yang menulis dalam bukunya, The Fourth Industrial Revolution bahwa konsep itu telah mengubah hidup dan kerja manusia. Dalam pada itu Dosen Institut Teknologi Bandung (ITB), Richard Mengko, yang mengambil sumber dari A.T. Kearney, mengungkap sejarah revolusi industri yang sampai akhirnya menyentuh generasi ke-4 ini (Hoedi Prasetyo, 2018). Berikut ini empat tahap evolusi industri dari dahulu hingga kini.

1. Akhir abad ke-18 Revolusi industri yang pertama terjadi pada akhir abad ke-18. Ditandai dengan ditemukannya alat tenun mekanis pertama pada 1784. Kala itu, industri diperkenalkan dengan fasilitas produksi mekanis menggunakan tenaga air dan uap. Peralatan kerja yang awalnya bergantung pada tenaga manusia dan hewan akhirnya digantikan dengan mesin tersebut. Banyak orang menganggur tapi produksi diyakini berlipat ganda.

2. Awal abad ke-20 Revolusi industri 2.0 terjadi di awal abad ke-20. Kala itu ada pengenalan produksi massal berdasarkan pembagian kerja. Lini produksi pertama melibatkan rumah potong hewan di Cincinnati, Amerika Serikat, pada 1870.

3. Awal 1970 Pada awal tahun 1970 ditengarai sebagai perdana kemunculan revolusi industri 3.0. Dimulai dengan penggunaan elektronik dan teknologi informasi guna otomatisasi produksi. Debut revolusi industri generasi ketiga ditandai dengan kemunculan pengontrol logika terprogram pertama (PLC), yakni modem 084-969. Sistem otomatisasi berbasis komputer ini membuat mesin industri tidak lagi dikendalikan manusia. Dampaknya memang biaya produksi menjadi lebih murah.

4. Awal 2018 Nah, sekaranglah zaman revolusi industri 4.0 yang ditandai dengan sistem cyberphysical. Saat ini industri mulai menyentuh dunia virtual, berbentuk konektivitas manusia, mesin dan data, semua sudah ada di mana- mana. Istilah ini dikenal dengan nama internet of things (loT). Tentunya, Pemerintah Republik Indonesia melihat peluang ini dan dianggap bisa menyumbang penciptaan lapangan kerja lebih banyak serta investasi baru yang berbasis teknologi. Sehingga dibentuklah roadmap dengan nama "Making Indonesia 4.0".

\section{Pengertian Pasar Modal}

Pasar modal berdasarkan UndangUndang Pasar Modal (UUPM) No.8 tahun 1995 Pasal 1 Nomor 13 menjelaskan, pasar modal adalah kegiatan yang bersangkutan dengan penawaran umum dan perdagangan efek, perusahaan publik yang berkaitan dengan efek yang diterbitkannya, serta lembaga dan profesi yang berkaitan dengan efek. Dalam UUPM tersebut tidak dipisahkan antara pasar modal syariah dengan pasar modal konvensional. Pasar modal mempunyai peran penting sebagai sarana investasi jangka panjang dalam perekonomian (Susilawati, n.d.). Pasar modal Indonesia berada di bawah naungan Otoritas Jasa Keuangan (OJK). Sebagaimana menurut Yenni Samri Juliati Nasution dalam tulisannya menjelaskanlembaga-lembaga yang terlibat di pasar modal adalah meliputi:

1. Perusahaan Emiten Adalah perusahaan yang akan melakukan penjualan surat-surat berharga.

2. Investor

Merupakan penanam modal yang akan membeli atau menanamkan modalnya di perusahaan yang melakukan emisi. Sebelum membeli surat berharga yang ditawarkan investor harus melakukan penelitian dan analisis tertentu.

3. Bank Kustodian

Bank yang merupakan tempat menyimpan modal investor yang akan dikelola oleh perusahaan emiten.

4. Lembaga penunjang Lembaga penunjang yang dimaksud adalah meliputi; Penjamin emisi (underwriter), perantara pedagang efek 
(broker/pialang), pedagang efek (dealer), penanggung (buarantor), wali amanat (trustee). Instrumen Utama.

Pasar Modal Adapun masing-masing jenis instrumen utama pada pasar modal adalah antara lain;

1. Saham (Stock)

Merupakan surat berharga yang bersifat kepemilikan, artinya pemilik saham merupakan pemilik perusahaan. Semakin besar saham yang dimilikinya, maka semakin besar pula kekuasaannya di perusahaan tersebut. Keuntungan yang diperoleh dari saham dikenal dengan nama deviden (Susilawati, n.d.).

2. Surat berharga

Obligasi merupakan instrument uutang bagi perusahaan yang hendak memperoleh modal. Obligasi secara ringkasnya adalah utang tetapi dalam bentuk sekuriti. "penerbit' obligasi adalah sipeminjam ataupun debitur. Sedangkan "pemegang" obligasi adalah pemberi pinjaman atau kreditur dan "kupon" obligasi adalah bunga pinjaman yang harus dibayar oleh debitur kepada kreditur. Dengan penerbitan obligasi ini maka dimungkinkan bagi penerbit obligasi guna memperoleh pembayaran investasi jangka panjangnya dengan sumber dana dari luar perusahaan.

\section{Minat Investasi}

Minat dalam Kamus Besar Bahasa Indonesia (KBBI) diartikan sebagai kecenderungan hati yang tinggi terhadap sesuatu gairah ataupun keinginan. Sementara menurut Lilis dalam tulisannya menyatakan bahwa minat merupakan fungsi kejiwaan atau sambutan yang sadar untuk tertarik terhadap suatu objek baik berupa benda atau yang lain. Selain itu minat dapat timbul karena ada gaya tarik dari luar dan juga datang dari hati sanubari. Minat yang besar terhadap suatu hal merupakan modal besar untuk mencapai tujuan yang diminati dalam hal ini berinvestasi terutama di sektor pasar modal (Marianto, 2017) . Dalam penelitianya dikatakan juga bahwa indikator dari seseorang berminat atau tidak maka dibutuhkan deskripsi yang jelas mengenai keberminatan seseorang, hal ini bisa kita lihat dari keaktifan seseorang dalam mencari informasi, mengidentifikasi semua persoalan yang di minati, menganalisis, dan membuat daftar table tentang sesuatu yang di minati hingga penetapan bidang yang di minati.

Dalam sistem ekonomi konvensional, seseorang melakukan investasi dengan motif yang berbeda-beda, salah satunya adalah untuk memenuhi kebutuhan likuiditas, menabung dengan tujuan mendapatkan pengembalian yang lebih besar, merencanakan pensiun dan bahkan untuk berspekulasi.

\section{Faktor-Faktor Yang Mempengaruhi Minat Investasi}

Menurut Daniel Raditya T.20 dalam tulisannya menjelaskan beberapa faktor faktor yang berpengaruh terhadap minat berinvestasi (Latifah, 2019), adalah antara lain:

1. Neutralinformation, adalah informasi yang berasal dari luar, memberikan informasi tambahan agar informasi yang dimiliki oleh calon investor menjadi lebih komprehensif.

2. Personalfinancialneeds, adalah informasi pribadi yang diperoleh selama investor tersebut berkecimpung dalam dunia investasi yang dapat menjadi semacam pedoman bagi investor tersebut dalam investasi berikutnya.

3. Self image/firm image coincidence, adalah informasi yang berhubungan dengan peniliaian terhadap citra perusahaan.

4. Socialrelevance, adalah informasi yang menyangkut posisi saham perusahaan di bursa, tanggung jawab perusahaan terhadap lingkungan sekitar serta area operasional perusahaan, nasional atau internasional.

5. Classic, merupakan kemampuan investor untuk menentukan kriteria ekonomis perilaku.

6. Professional recommendation, merupakan pendapat, saran, atau 
rekomendasi dari pihak-pihak, saran, atau rekomendasi dari pihak-pihak, professional atau para ahli di bidang investasi.

\section{Keputusan Investasi}

Menurut (PSAK Nomor 13 dalam Standar Akuntansi Keuangan 2012) Investasi adalah suatu aktiva yang digunakan perusahaan untuk pertumbuhan kekayaan (accretion of wealth) melalui distribusi hasil investasi (seperti bunga, royalti, dividen, dan uang sewa), untuk apresiasi nilai investasi, atau untuk manfaat lain bagi perusahaan yang berinvestasi seperti manfaat yang diperoleh melalui hubungan perdagangan. Peluang investasi sangat mempengaruhi nilai perusahaan. Pengeluaran investasi memberikan sinyal positif tentang pertumbuhan perusahaan di masa yang akan datang, sehingga meningkatkan harga saham sebagai indikator nilai perusahaan (signaling theory). Jenis pengeluaran modal memiliki pengaruh besar terhadap nilai perusahaan karena informasi tersebut membawa informasi tentang pertumbuhan pendapatan yang diharapkan di masayang akan datang (ERLINA, 2015).

\section{Aplikasi Investasi}

Invisee adalah salah satu aplikasi dari sekian banyak aplikasi investasi yang digunakan untuk mempermudah masyarakat dalam melakukan investasi. Aplikasi ini dihadirkan langsung oleh PT.Nusantara Sejahtera Investama (NSI) sebagai sebuah aplikasi marketplace (Powell, 2019) khusus produksi investasi dan suatu media aplikasi dalam menunjang kegiatan investasi di reksadana secara on-line. Invisee sudah ada sejak Januari 2017. Dalam peluncuran aplikasi invisee, NSI memberikan sejumlah pembaruan, yaitu fitur bantuan dalam registrasi dan tersedianya Invisee dalam platform iOS. Pilihan produk yang ada di Invisee ada berbagai jenis diantaranya sebagai berikut :
1. Reksadana pasar uang

Reksadana jenis ini cocok cocok digunakan bagi masyarakat yang ingin menginvestasikan dana selama 1-2 tahun dengan alokasi investasi $100 \%$ pada giro, deposito, surat hutangberjangka waktu $<1$ tahun.

2. Reksadana pendapatan tetap Reksadana jenis ini cocok untuk masyarakat yang ingin menginvestasikan dana selama 2-3 tahun, dengan alokasi investasi minimal $80 \%$ pada surat hutang.

3. Reksadana campuran

Reksadana jenis ini cocok untuk masyarakat yang ingin menginvestasikan dana selama 3-5 tahun, dengan alokasi investasi maksimal $79 \%$ pada surat hutang atau pasar uang.

4. Reksadana saham

Reksadana jenis ini cocok untuk masyarakat yang ingin menginvestasikan dana selama 5 tahun, dengan alokasi investasi minimal $80 \%$ pada saham.

5. Reksadana terproteksi

Reksadana jenis ini cocok untuk masyarakat yang ingin menginvestasikan dana dengan minimum selama 3 tahun, dengan alokasi investasi $100 \%$ pada giro, deposito, surat hutang berjangka waktu $<1$ tahun.

Melalui invisee ini diharapkan akan memberikan manfaat kepada calon investor diantaranya :

1. Membantu calon investor untuk berinvestasi di reksadana sesuai dengan tujuan dan kebutuhan.

2. Sebagai media edukasi kepada masyarakat luas dalam mensosialisasikan reksadana.

3. Memudahkan calon investor dalam melakukan transaksi serta melakukan pemantauan investasinya di reksadana.

\section{HIPOTESIS}

Atas dasar landasan teori diatas, maka Penulis menggunakan hipotesis penelitian sebagai berikut :

1. Diduga bahwa di Era Revolusi Industri 4.0 banyak masyarakat serta 
mahasiswa Fakultas Ekonomi

Universitas Bangka Belitung yang belum bergabung sehingga rendahnya tingkat investasi di pasar modal.

2. Diduga sosialisasi yang dilakukan seperti "Yuk Nabung Saham " serta

aplikasi investasi "Invisee" memberikan pengaruh terhadap keputusan berinvestasi masyarakat serta mahasiswa Fakultas Ekonomi Universitas Bangka Belitung di pasar modal.

\section{METODE PENELITIAN}

Dalam penelitian ini penulis menggunakan metode deskriptif verifikatif dengan tujuan menjelaskan, meringkaskan berbagai kondisi, berbagai situasi, atau berbagai variabel yang timbul dimasyarakat dan mahasiswa Fakultas Ekonomi Universitas Bangka Belitung yang menjadi objek penelitian itu berdasarkan apa yang terjadi. Kemudian mengangkat kepermukaan karakter atau gambaran tentang kondisi, pengaruh ataupun variabel tersebut. Jenis data dalam penelitian ini ada dua macam, yaitu jenis data primer dan data sekunder.

1. Data primer yaitu data yang dibuat oleh peneliti untuk maksud khusus menyelesaikan permasalahan yang sedang ditanganinya. Data dikumpulkan sendirioleh peneliti langsung dari sember pertama atau keempat objek penelitian dilakukan.

2. Data sekunder yaitu data yang telah dikumpulkan untuk maksud selain menyelesaikan masalah yang sedang dihadapi. Data ini dapat ditemukan dengan cepat. Dalam penelitian ini yang menjadi sumber data sekunder adalah literatur, artikel, jurnal, serta situs di internet yang berkenaan dengan penelitian yang dilakukan.

Metode pengumpulan data yang digunakan adalah :
1. Penelitian kepustakaan (Library Research)

Dalam penelitian ini penulis mengumpulkan data dengan cara membaca, mempelajari dan menelaah literatur-literatur yang relevan dengan topik yang dibahas. penelitian kepustakaan dimaksudkan untuk memperoleh data sekunder dalam menunjang data primer yang telah didapat dari penelitian lapangan.

2. Penelitian lapangan (Field Research) Untuk mendapatkan data primer dilakukan dengan cara penyebaran kuisioner dan wawancara. Teknik yang digunakan dalam pengambilan sampel adalah total sampling atau sampel jenuh dan sering disebut sebagai sensus, dimana seluruh populasi digunakan sebagai sampel. Sampel jenuh yaitu teknik penentuan sampel dengan cara mengambil seluruh anggota populasi sebagai responden atau sampel. Peneliti mengambil seluruh populasi mahasiwa Fakultas Ekonomi Universitas Bangka Belitung pada tahun 2019 yang berjumlah 50 orang untuk dijadikan responden. Untuk menjawab tujuan pertama dan hipotesis pertama digunakan analisis deskriptif dengan alat analisis rentang skala Likert. Dalam penelitian ini variabel $x$ atau variabel bebasnya adalah; $\mathrm{X} 1=$ Seminar pasar modal, X2 = kampanye Yuk Nabung Saham, $X 3=$ aplikasi investasi (Invisee). $Y=$ keputusan berinvestasi pada pasar modal. Dari ,masing-masing variabel akan dilihat skala penilaian keputusan berinvestasi pada pasar modal di Era Industri 4.0. 
ISSN $1412-2936$

EISSN 2549-7308

Table 4.1

Tingkat keeratan Hubungan

\begin{tabular}{c|c}
\hline Interval koefisien & Tingkat keeratan Hubungan \\
\hline $0,80-1$ & Sangat kuat \\
\hline $0,60-0,799$ & Kuat \\
\hline $0,40-0,599$ & Cukup \\
\hline $0,20-0,399$ & Lemah \\
\hline $0,00-0,199$ & Sangat lemah \\
\hline
\end{tabular}

\section{HASIL DAN PEMBAHASAN}

Analisis pengaruh antara variabel strategi sosialisasi pasar modal, terhadap keputusan berinvestasi di pasar modal di era Revolusi Industri

\section{0 secara parsial.}

Untuk mengetahui seberapa akurat variabel strategi sosialisasi pasar modal

1. Membuat Hipotesisi dalam bentuk kalimat

Ho : Tidak ada pengaruh secara parsial antara variabel strategi sosialisasi pasar modal melalui seminar pasar modal terhadap keputusan berinvestasi di pasar modal pada era digital.

$\mathrm{Ha}$ : Terdapat pengaruh secara parsial antara variabel strategi sosialisasi modal melalui seminar pasar modal terhadap keputusan melalui seminar pasar modal (variabel X1) mempengaruhi keputusan berinvestasi pada pasar modal (variabel Y) di era revolusi industri 4.0 (Sulastyawati, Kurniawan, Modal, Berinvestasi, \& Modal, n.d.).

2. Menginput, mengelola data dengan aplikasi software statistic SPSS 17 dan summary outputnya akan diinterpretasikan sesuai dengan angka-angka yang tertera pada tabel output summary yang dikelola

Tabel 4.2

Variables Entered/Removed ${ }^{\mathrm{b}}$

\begin{tabular}{c|c|c|c}
\hline Metode & Variabless Entered & Variables removed & method \\
\hline 1 & Seminar pasar modal & & enter \\
\hline
\end{tabular}

(sumber ; Data yang diolah)

Jika dilihat nilai korelasi $(R)=0,520$, artinya korelasi antara variabel strategi sosialisasi dan edukas pasar modal melalui seminar pasar modal dengan variabel keputusan berinvestasi di pasar modal memiliki hubungan yang sedang, karena nilai korelasi tidak mendekati nol atau 1.

Tabel 4.3

Uji Aotokorelasi variabel X1 Y

\begin{tabular}{c|c|c|c|c|c}
\hline Model & $\mathrm{R}$ & $\mathrm{R}$ square & $\begin{array}{c}\text { Adjusted } \mathrm{R} \\
\text { square }\end{array}$ & $\begin{array}{c}\text { Std. Error of the } \\
\text { estimate }\end{array}$ & Durbin watson \\
\hline 1 & 520 & .270 & .255 & 7.038 & 1.360 \\
\hline
\end{tabular}


ISSN 1412-2936

EISSN 2549-7308

\section{(sumber ; Data yang diolah)}

Nilai $R$ square 0.270 , yang artinya pengaruh antara sosialisasi pasar modal melalui seminar pasar modal terhadap keputusan berinvestasi di pasar modal di era digital adalah sebesar $27 \%$. Yang artinya persentase pengaruh sosialisasi pasar modal melalui seminar pasar modal terhadap keputusan berinvestasi di pasar modal adalah cukup kecil atau tidak begitu 
mempengaruhi.

Tabel 4.4

Uji t hitung (parsial) variabel $X 1$ dan $Y$

Coefficient

\begin{tabular}{l|l|l|l|l|l}
\hline \multirow{2}{*}{ Model } & \multicolumn{2}{|l|}{ Unstandardised coefficient } & $\begin{array}{l}\text { standardised } \\
\text { coefficient }\end{array}$ & $\mathrm{t}$ & Sig. \\
\cline { 2 - 6 } & $\mathrm{B}$ & Std.error & beta & & \\
\hline Constant & 14.411 & 8.965 & & 1604 & 120 \\
\hline $\begin{array}{l}\text { Seminar } \\
\text { pasar modal }\end{array}$ & 641 & 157 & 520 & 4.177 & 000 \\
\hline
\end{tabular}

(sumber ; Data yang diolah)

a. Dependent variable minat berinvestasi Seminar pasar modal adalah sebagai variabel bebas (independent variable) atau predictor atau variabel yang mempengaruhi. Keputusan berinvestasi di pasar modal sebagai variabel terikat (independent variabel)atau variabel yang dipengaruhi. Dari table tersebut dapat dibuat persamaan regresi berdasarkan variabel di atas, yaitu;

$Y=14.411+0,641 \mathrm{X}$

Standar error atau nilai maksimum kesalahan yang dapat terjadi dalam memperkirakan populasi adalah sebesar 0,157. Nilai koefisien Beta pada standardized coefisien menunjukkan angka 0,520. Hal ini berarti 1 unit $((1 \times$ seminar $) / \%)$ yang diadakan akan meningkatkan minat investasi masyarakat di pasar modal sebesar $0.520 \%$. Nilai t hitung adalah pengujian signifikansi untuk mengetahui pengaruh variabel $\mathrm{X} 1$ terhadap variabel Y,apakah berpengaruh signifikan atau tidak. Untuk mengetahui hasilnya signifikan atau tidak, angka $t$ hitung akan dibandingkan dengan $t$ tabel sebagai berikut;

1. Merumuskan hipotesis

Ho : Tidak terdapat pengaruh secara parsial antara variabel strategi sosialisasi pasar modal melalui seminar pasar modal, terhadap keputusan berinvestasi di pasar modal.

$\mathrm{Ha}$ : Terdapat pengaruh secara parsial antara variabel strategi sosialisasi pasar modal melalui seminar pasar modal, terhadap keputusan berinvestasi di pasar modal.

2. Menentukan t hitung dan signifikansi Dari output didapat t hitung sebesar 4,177 dan signifikansi sebesar 0,000.

3. Menentukan t tabel

T tabel dapat dilihat pada tabel statistic signifikansi 0,05 dengan derajat kebebasan $\mathrm{df}=\mathrm{N}-4=50-$ $4=46$. Hasil yang dilihat dari t tabel adalah sebesar 2.416 .

4. Kriteria pengujian

a. Jika t hitung $>$ t tabel, maka Ho ditolak.

b. Jika t hitung < t tabel, maka Ho diterima. Berdasarkan signifikansi: c.Jika signifikansi > 0,05. Maka Ho diterima

d. Jika signifikansi $<0,05$. Maka Ho ditolak

5. Membuat kesimpulan

Karena nilai $\mathrm{t}$ hitung $>$ dari $\mathrm{t}$ tabel $(4.177>2.416)$ dan signifikansi $(0,00)$ $<0,05)$, maka Ho ditolak. Artinya ada pengaruh secara parsial antara variabel strategi sosialisasi pasar modal melalui seminar pasar modal terhadap keputusan berinvestasi di pasar modal di era digital ini.

Dari hasil kesimpulan di atas dapat ditarik suatu kesimpulan bahwa strategi sosialisasi pasar modal melalui 
seminar pasar modal mempengaruhi secara parsial keputusan berinvestasi di pasar modal. Dengan kata lain keberadaan seminar pasar modal yang dilaksanakan OJK secara parsial mempengaruhi responden memutuskan berinvestasi di pasar modal di era digital yang semakin canggih.

Analisis Pengaruh Antara Variabel Strategi Sosialisasi Pasar Modal Melalui Kampanye "Yuk Nabung Saham", Terhadap Keputusan Berinvestasi Di Pasar Modal Secara Parsial. Untuk mengetahui seberapa signifikan variabel strategi sosialisasi pasar modal melalui kampanye "Yuk Nabung Saham" (Variabel X2) mempengaruhi keputusan berinvestasi pada pasar modal (Variabel Y) maka dapat diketahui dengan melakukan langkah-langkah sebagai berikut:

1. Membuat Hipotesis dalam bentuk kalimat

Ho : Tidak terdapat pengaruh secara parsial antara variabel strategi sosialisasi pasar modal melalui kampanye "Yuk Nabung Saham", terhadap keputusan berinvestasi di pasar modal.

$\mathrm{Ha}$ : Terdapat pengaruh secara parsial antara variabel strategi sosialisasi pasar modal melalui "Yuk Nabung Saham", terhadap keputusan berinvestasi di pasar modal.

Secara statistic hipotesisnya adalah;

Ho $: b=0$

$\mathrm{Ha}: \mathrm{b} \neq 0$

Tabel 4.5

Variables entered/removed

\begin{tabular}{l|l|l|l}
\hline Model & Variables entered & Variables removed & Method \\
\hline 1 & $\begin{array}{c}\text { Kampanye yuk nabung } \\
\text { saham }\end{array}$ & & Enter \\
\hline
\end{tabular}

(sumber ; Data yang diolah)

Tabel 4.6

Uji Aotokorelasi variabel X2 Y

\begin{tabular}{l|l|l|l|l|l}
\hline Model & $R$ & R square & $\begin{array}{l}\text { Adjusted } \\
\text { square }\end{array}$ & $\begin{array}{l}\text { Std.error of the } \\
\text { estimate }\end{array}$ & $\begin{array}{l}\text { Durbin } \\
\text { watson }\end{array}$ \\
\hline 1 & 255 & 067 & 047 & 7.693 & 1961 \\
\hline
\end{tabular}

(sumber ; Data yang diolah)

a. Predictors : (constant), yuk nabung saham

b. Dependent variable:minat berinvestasi Jika dilihat nilai korelasi $(R)=0,255$, artinya korelasi antara variabelstrategi sosialisasi pasar modal melaluikampanye "Yuk Nabung Saham" dengan variabel keputusan berinvestasi di pasar modal memiliki hubungan yang lemah, karena nilai korelasi mendekati nol. Nilai $\mathrm{R}$ square 0.067 , yang artinya pengaruh antara sosialisasi pasar modal melalui seminar pasar modal terhadap keputusan berinvestasi di pasar modal adalah sebesar 6,7\%. Yang artinya persentase pengaruh sosialisasi pasar modal melalui seminar pasar modal terhadap keputusan berinvestasi di pasar modal adalah kecil 
Tabel 4.7

Uji t hitung (parsial) variabel X2 Y

\begin{tabular}{l|l|l|l|l|l}
\hline \multirow{2}{*}{ Model } & \multicolumn{2}{|l|}{ Unstandardised coefficient } & $\begin{array}{l}\text { standardised } \\
\text { coefficient }\end{array}$ & t & sig \\
\cline { 2 - 6 } & B & Std.error & beta & & \\
\hline constant & 36.009 & 8.454 & & 4265 & 000 \\
\hline $\begin{array}{l}\text { Yuk nabung } \\
\text { saham }\end{array}$ & 273 & 154 & 255 & 1801 & 0783 \\
\hline
\end{tabular}

(sumber ; Data yang diolah)

a. Dependent variable : minat berinvestasi

Kampanye "Yuk Nabung

Saham"adalah sebagai variabel bebas (independent variable) atau predictor atau variabel yang mempengaruhi. Keputusan berinvestasi di pasar modal sebagai variabel terikat (independent variabel)atau variabel yang dipengaruhi.

Dari tabel tersebut dapat dibuat persamaan regresi berdasarkan variabel di atas, yaitu

$\mathrm{Y}=36,009+0,273 \mathrm{X}$.

Standar error atau nilai maksimum kesalahan yang dapat terjadi dalam memperkirakan populasi adalah sebesar 0,154. Nilai koefisien Beta pada standardized coefisien menunjukkan angka 0,255. Penambahan kampanye "Yuk Nabung Saham" sebesar $1 \%$ akan meningkatkan minat investasi masyarakat di pasar modal sebesar $0,255 \%$.

Nilai $t$ hitung adalah pengujian signifikansi untuk mengetahui pengaruh varabel $\mathrm{X} 2$ terhadapvariabel $\mathrm{Y}$, apakah berpengaruh signifikan atau tidak. Untuk mengetahui hasilnya signifikan atau tidak, angka t hitung akan dibandingkan dengan $t$ tabel sebagai berikut :

1. Merumuskan hipotesis Ho : Tidak terdapat pengaruh secara parsial antara variabel strategi sosialisasi pasar modal melalui kampanye "Yuk Nabung Saham", terhadap keputusan berinvestasi di pasar modal.

$\mathrm{Ha}$ : Terdapat pengaruh secara parsial antara variabel strategi sosialisasi pasar modal melalui "Yuk Nabung Saham", terhadap keputusan berinvestasi di pasar modal.

2. Menentukan t hitung dan signifikansi Dari output didapat t hitung sebesar 1,801 dan signifikansi sebesar 0,083.

3. Menentukan t tabel

T tabel dapat dilihat pada tabelstatistic signifikansi 0,05 dengan derajat kebebasan $\mathrm{df}=\mathrm{N}-4=50-4=46$. Hasil yang dilihat dari $\mathrm{t}$ tabel adalah sebesar 2.416

4. Kriteria pengujian
a. Jika t hitung $>t$ tabel, maka Ho ditolak.
b. Jika t hitung $<\mathrm{t}$ tabel, maka Ho diterima.

Berdasarkan signifikansi:
a. jika signifikansi $>0,05$. Maka Ho diterima
b. jika signifikansi $<0,05$. Maka Ho ditolak

5. Membuat kesimpulan

Karena nilai $\mathrm{t}$ hitung $<$ dari $\mathrm{t}$ tabel $(1,801<2.416)$ dan (signifikansi) 0,079 $>0,05$, maka Ho diterima. Artinya tidak ada pengaruh secara parsial antara variabel strategi sosialisasi pasar 
modal melalui kampanye "Yuk Nabung Saham" terhadap keputusan berinvestasi di pasar modal pada era digital.

Dari hasil kesimpulan di atas dapat disimpulkan bahwa strategi sosialisasi pasar modal melalui kampanye "Yuk Nabung Saham" tidak mempengaruhi secara parsial keputusan berinvestasi di pasar modal. Dengan kata lain keberadaan kampanye "Yuk Nabung Saham" yang dilaksanakan OJK secara parsial mempengaruhi responden memutuskan berinvestasi di pasar modal.

Analisis pengaruh antara variable strategi sosialisasi pasar modal melalui aplikasi investasi (Invisee), terhadap keputusan berinvestasi di pasar modal secara parsial.

Bagaimana variabel strategi sosialisasi pasar modal melalui aplikasi investasi (Invisee) mempengaruhi secara parsial keputusan berinvestasi pada pasar modal, berikut analisanya.
Untuk mengetahui seberapa signifikan variabel strategi sosialisasi pasar modal melalui aplikasi investasi (variabel X3) mempengaruhi keputusan berinvestasi pada pasar modal (Variabel Y) maka dapat diketahui dengan melakukan langkahlangkah sebagai berikut:

1. Membuat Hipotesis dalam bentuk kalimat.

Ho : Tidak terdapat pengaruh secara parsial antara variabel strategi sosialisasi pasar modal melalui aplikasi investasi, terhadap keputusan berinvestasi di pasar modal.

$\mathrm{Ha}$ : Terdapat pengaruh secara parsial antara variabel strategi sosialisasi pasar modal melalui aplikasi investasi, terhadap keputusan berinvestasi di pasar modal.

Secara statistic hipotesisnya adalah;

Ho: $b=0$

$\mathrm{Ha}: \mathrm{b} \neq 0$

Tabel 4.8

Variables entered/removed

\begin{tabular}{c|c|c|c}
\hline Model & Variables entered & Variables removed & Method \\
\hline 1 & $\begin{array}{c}\text { Aplikasi Investasi } \\
\text { (Invisee) }\end{array}$ & & Enter \\
\hline
\end{tabular}

(sumber ; Data yang diolah)

Tabel 4.9

Uji Autokorelasi Variabel X3 dan Y

\begin{tabular}{l|l|l|l|l|l}
\hline \multirow{2}{*}{ Model } & \multicolumn{2}{|l|}{ Unstandardised coefficient } & $\begin{array}{l}\text { standardised } \\
\text { coefficient }\end{array}$ & $\mathrm{t}$ & Sig. \\
\cline { 2 - 6 } & $\mathrm{B}$ & Std.error & beta & & \\
\hline constant & 39972 & 9349 & & 4.281 & .000 \\
\hline Aplikasi investasi & 186 & 156 & 174 & 1.199 & .242 \\
\hline
\end{tabular}

(sumber ; Data yang diolah) 
a. Dependent variable : minat berinvestasi

Aplikasi investasi adalah sebagai variabel bebas (independent variable) atau predictor atau variabel yang mempengaruhi. Keputusan berinvestasi di pasar modal sebagai variabel terikat (independent variabel) atau variabel yang dipengaruhi. Dari tabel tersebut dapat dibuat persamaan regresi berdasarkan variabel di atas, yaitu;
$\mathrm{Y}=39,972+0,186 \mathrm{X}$

Standar error atau nilai maksimum kesalahan yang dapat terjadi dalam memperkirakan populasi adalah sebesar 0,156 . Nilai koefisien Beta pada standardized coefisien menunjukkan angka 0,174 . Hal ini berarti setiap kali (1\%) menggunakan aplikasi investasi akan terjadi peningkatan minat investasi masyarakat sebesar $0.174 \%$.

Tabel 4.10

Uji t hitung (parsial) variabel X3 dan Y Coefficient

\begin{tabular}{l|l|l|l|l|l}
\hline Model & $\mathrm{R}$ & R square & Adjusted R square & $\begin{array}{l}\text { Std.error of the } \\
\text { estimate }\end{array}$ & $\begin{array}{l}\text { Durbin } \\
\text { watson }\end{array}$ \\
\hline 1 & 174 & 033 & 013 & 7832 & 1936 \\
\hline
\end{tabular}

(sumber ; Data yang diolah)

a. Predictors: (Constant), aplikasi investasi

b. Dependent Variable: Minat Berinvestasi

Jika dilihat nilai korelasi $(R)=0,174$, artinya korelasi antara variabel strategi sosialisasi pasar modal melalui aplikasi investasi dengan variabel keputusan berinvestasi di pasar modal memiliki hubungan yang lemah, karena nilai korelasi mendekati nol. Nilai $R$ square 0,033 , yang artinya pengaruh antara sosialisasi pasar modal melalui aplikasi investasi terhadap keputusan berinvestasi di pasar modal adalah sebesar 3,3\%. Yang artinya persentase pengaruh sosialisasi pasar modal melalui aplikasi investasi terhadap keputusan berinvestasi di pasar modal adalah kecil.

Dari hasil kesimpulan di atas dapat disimpulkan bahwa strategi sosialisasi pasar modal melalui seminar pasar modal, kampanye "Yuk Nabung Saham" dan aplikasi investasi mempengaruhi secara simultan (bersama-sama) keputusan berinvestasi di pasar modal. Dengan kata lain keberadaan seminar pasar modal, kampanye "Yuk Nabung Saham" dan aplikasi investasi yang dilaksanakan OJK secara simultan (bersama-sama) mempengaruhi responden memutuskan berinvestasi di pasar modal.

\section{KESIMPULAN}

Berdasarkan hasil dan pembahasan

dalam penelitian tentang pengaruh antara sosialisasi seminar pasar modal, Yuk Nabung Saham, dan aplikasi investasi di Era Revolusi Industri 4.0 terhadap mahasiswa Jurusan Manajemen Fakultas Ekonomi Universitas Bangka Belitung dalam investasi di pasar modal, dapat disimpulkan sebagai berikut :

1. Strategi sosialisasi pasar modal melalui seminar pasar modal di Era Revolusi Industri 4.0 berpengaruh terhadap keputusan responden untuk berinvestasi. Hal ini dapat dilihat dari variabel seminar pasar modal bahwa t hitung untuk variabel seminar pasar modal (X1) sebesar 4,177, $t$ tabel sebesar 2,416 dengan nilai signifikansi sebesar 0,000 . Berarti $\mathrm{H}_{\mathrm{a}}$ diterima dan $\mathrm{H}_{0}$ ditolak. Dikarenakan $\mathrm{t}$ hitung $>\mathrm{t}$ tabel $(4,177>2,416)$ dan signifikan karena nilai signifikansi 
$0,000<0,005$. Sehingga dapat penulis simpulkan bahwa seminar pasar modal secara parsial berpengaruh terhadap keputusan berinvestasi.

2. Strategi sosialisasi pasar modal melalui kampanye "Yuk Nabung Saham" berpengaruh terhadap keputusan responden untuk berinvestasi. Hal ini dapat dilihat dari variabel kampanye "Yuk Nabung Saham"bahwa t hitung untuk variabel kampanye "Yuk Nabung Saham" (X2) sebesar 1,801 dan t tabel sebesar 2,416 dengan nilai signifikansi sebesar 0,083 . Berarti $\mathrm{H}_{0}$ diterima dan $\mathrm{H}_{\mathrm{a}}$ ditolak. Dikarenakan $\mathrm{t}$ hitung $<\mathrm{t}$ tabel $(1,801<2,416)$ dan tidak signifikan karena nilai signifikansi $0,083>0,005$. Sehingga dapat penulis simpulkan bahwa seminar pasar modal secara parsial tidak berpengaruh terhadap keputusan berinvestasi.

3. Strategi sosialisasi pasar modal melalui aplikasi investasi tidak berpengaruh terhadap keputusan responden untuk berinvestasi. Hal ini dapat dilihat dari variabel aplikasi investasi bahwa Nilai $R$ square 0,033 , yang artinya pengaruh antara sosialisasi pasar modal melalui aplikasi investasi terhadap keputusan berinvestasi di pasar modal adalah sebesar 3,3\%. Yang artinya persentase pengaruh sosialisasi pasar modal melalui aplikasi investasi terhadap keputusan berinvestasi di pasar modal adalah kecil.

Sehingga dapat penulis simpulkan bahwa aplikasi investasi secara parsial tidak berpengaruh terhadap keputusan berinvestasi. Dengan asumsi bahwa faktor lain yang mempengaruhi adalah akses dan ketersediaan dana yang dimiliki responden.

4. Sosialisasi pasar modal melalui seminar pasar modal, kampanye "Yuk Nabung Saham", dan aplikasi investasi secara simultan (bersama-sama) mempengaruhi keputusan berinvestasi.

\section{SARAN PENELITIAN}

Adapun saran-saran yang dapat diberikan melalui hasil penelitian ini agar mendapatkan hasil yang lebih baik, yaitu:

1. Bagi pemerintah khususnya Lembaga yang terkait dengan masalah pasar modal seperti OJK,KSPEI dan lainnya agar bisa membuat suatu kegiatan yang berbeda, menarik dan memudahkan masyarakat untuk berinvestasi di pasar modal.

2. Untuk penelitian selanjutnya disarankan untuk menambah variable penelitian untuk mempermudah dalam mengetahui apa saja yang menjadi dasar ketertarikan masyarakat berinvestasi di pasar modal pada era revolusi Industri 4.0.

\section{REFERENSI}

Erlina. (2015). Analisis pengaruh keputusan investasi, keputusan pendanaan, kebijakan dividendan tingkat suku bunga terhadap nilai perusahaan.

Harry, N. (2017). KSEI Terus Upayakan Kemudahaan Pembukaan Rekening Investasi. 1-4.

Hoedi Prasetyo, W. S. (2018). Industri 4.0: telaah klasifikasi aspek dan arah perkembangan riset. 13(1), 17-26.

Kustodian, P. T., \& Efek, S. (2018). 21 Tahun KSEI: Inovasi Untuk Kenyamanan Transaksi di Pasar Modal. 1-3.

Latifah, S. (2019). PENGARUH PENGETAHUAN , MODAL MINIMAL DAN MOTIVASI INVESTASI TERHADAP MINAT MAHASISWA UNTUK BERINVESTASI DI PASAR MODAL SYARIAH ( Studi Pada Galeri 
Investasi Syari ' ah UMP ) SKRIPSI JURUSAN EKONOMI SYARI' $A H$ FAKULTAS EKONOMI DAN BISNIS ISLAM INSTITUT AGAMA ISLAM NEGERI ( IAIN ) PURWOKERTO.

Mar'ati, F. S. (n.d.). MENGENAL PASAR MODAL. 79-88.

Marianto, 2015. (2017). intensi berinvestasi dalam diri mahasiswa dan non- mahasiswa. 2-7.

Mubarok, F. K. (2018). Peran sosialisasi dan edukasi dalam menumbuhkan minat investasi di pasar modal syariah The role of socialization and education in growing interest in investment in the sharia capital market. 14(2), 113-122.

Powell, J. (2019). Generali market update. (February), 1-2.

Riyadi, A. (n.d.). analisis FAKTORFAKTOR YANG MEMPENGARUHI MINAT MAHASISWA UNTUK BERINVESTASI DI PASAR MODAL (STUDI PADA MAHASISWA FAKULTAS EKONOMI DAN BISNIS ISLAM UIN SUNAN KALIJAGA YOGYAKARTA). Skripsi.

Rohida, L., Sos, S., \& Si, M. (2018). Pengaruh Era Revolusi Industri 4 . 0 terhadap Kompetensi Sumber Daya Manusia. 6, 114-136.

Satya, V. E. (2018). STRATEGI INDONESIA MENGHADAPI.

Sulastyawati, D., Kurniawan, O., Modal, P., Berinvestasi, K., \& Modal, P. (n.d.). ANALISIS STRATEGI SOSIALISASI PASAR MODAL $D A N$.

Susilawati, R. A. E. (n.d.). REAKSI PASAR MODAL TERHADAP PENGUMUMAN. 57-69.

Wibowo, A. (2019). PENGARUH PENGETAHUAN INVESTASI, KEBIJAKAN MODAL MINIMAL INVESTASI, DAN PELATIHAN PASAR MODAL TERHADAP MINAT INVESTASI (Studi Kasus Mahasiswa FE Unesa Yang Terdaftar Di Galeri Investasi FE Unesa). 7, 192-201. 